\title{
Photodynamic inactivation of the phytopathogenic bacterium Xanthomonas citri subsp. citri
}

\begin{tabular}{|r|l|}
\hline Journal: & Applied Microbiology \\
\hline Manuscript ID & Draft \\
\hline Journal Name: & Letters in Applied Microbiology \\
\hline Manuscript Type: & LAM - Original Article \\
\hline Date Submitted by the & nuthor: \\
\hline Complete List of Authors: & $\begin{array}{l}\text { Ndmueda, Anastasia; University of Aveiro, Department of Biology } \\
\text { Pereira, Inês; University of Aveiro, Department of Chemistry } \\
\text { Faustino, M. Amparo; University of Aveiro, Department of Chemistry } \\
\text { Cunha, Angela; University of Aveiro, Department of Biology/CESAM }\end{array}$ \\
\hline Key Words: & Biofilms, Plant diseases, Biocontrol, Biocides, Agriculture \\
\hline &
\end{tabular}

\section{SCHOLARONE Manuscripts}


1 Photodynamic inactivation of the phytopathogenic bacterium

2 Xanthomonas citri subsp. citri

3 Anastasia Ndemueda ${ }^{1}$, Inês Pereira ${ }^{1}$, Faustino, M.A.F. ${ }^{2}$, Cunha, Â. ${ }^{1}$

$4{ }^{1}$ CESAM and Department of Biology, University of Aveiro, Campus de Santiago, 3810-

5193 Aveiro, Portugal

$6 \quad{ }^{2}$ LAQV-REQUIMTE and Department of Chemistry, University of Aveiro, 3810-193

7 Aveiro, Portugal

8

9 Corresponding author: Ângela Cunha acunha@ua.pt

10

\section{Statement of contribution}

All authors contributed substantially to the conception and design of the work or the acquisition and analysis of data, to the drafting or critical revision of the manuscript and approved the final submitted version.

\section{Abbreviated running headline}

Photoinactivation of Xanthomonas citri

\section{Significance and impact of the study (100 words)}

This study demonstrates for the first time that the causative agent of citrus canker, Xanthomonas citri subsp. citri is susceptible to photodynamic inactivation and that biofilms can be eradicated with the phenothiazine dye Toluidine Blue $\mathrm{O}(50 \mu \mathrm{M})$ in presence of a non-toxic concentration of $\mathrm{KI}(100 \mathrm{mM})$ upon exposure to natural sunlight. 


\section{Abstract}

The present work intended to evaluate the applicability of photodynamic inactivation (PDI) of Xanthomonas citri subsp. citri with toluidine blue O (TBO), a commercial photosensitizer, as a strategy to control citrus canker.

Assays were conducted with cell suspensions and biofilms constructed either on polypropylene microtubes (in vitro assays) or on the surface of orange leaves (ex vivo assays), in the presence of TBO and under artificial white light irradiation or natural sunlight.

PDI assays using TBO alone caused a maximum $5.8 \log$ reduction of Xanthomonas citri viable cells in suspensions, and much smaller inactivation $(1.5 \mathrm{log})$ when in biofilm forms. However, concomitant use of KI potentiated the TBO photosensitization. Biofilms were completely eradicated (> $6 \log$ reduction) with $5.0 \mu \mathrm{M}$ TBO $+10 \mathrm{mM} \mathrm{KI}$ (in vitro) or $5.0 \mu \mathrm{M} \mathrm{TBO}+100 \mathrm{mM} \mathrm{KI}$ (ex vivo) after artificial white light irradiation. Under natural sunlight irradiation conditions, complete eradication was achieved with $50 \mu \mathrm{M}$ TBO and $100 \mathrm{mM} \mathrm{KI}$.

PDI has potential to be applied in the control of citrus canker in field conditions although further studies are needed to show that there are no risks to plant physiology or fruit quality.

Keywords: citrus canker; toluidine blue O; potassium iodide; phytopathogens; photosensitization; 


\section{Introduction}

Citrus cancer is a globally occurring infectious disease caused by the gramnegative phytopathogenic bacterium Xanthomonas citri subsp. citri $[$ syn. X. campestris pv. citri, Xanthomonas axonopodis pv citri (Behlau \& Belasque, 2014)]. The disease causes defoliation and premature fruit drop. Leaf loss compromises the photosynthetic area resulting in lower productivity and the appearance of injuries and fall of fruits before harvest causes losses of up to $80 \%$ (Lanza et al. 2018).

Cupric bactericides still represent the most popular chemical approach (Behlau et al. 2017). However, they have a strictly preventive character, showing neither curative efficacy nor systemic activity in the plant (Lamichhane et al. 2018). On the other hand, the application of copper-based biocides may induce bacterial resistance to biocides in soil microbes (Glibota et al. 2019) and phytopathogens (Roach et al. 2020). In fact, the first copper-resistant $X$. citri strain $(X$. citri $\mathrm{CuR})$ was reported in nurseries that received regular applications of copper-based bactericides (Canteros et al. 2008). With the aim of increasing the efficiency of treatments while reducing the impact of undesirable sideeffects, compounds with low copper concentration, such as copper sulphate pentahydrate (Favaro et al. 2017), gallic acid esters (Savietto et al. 2018), zinc oxide nanoparticles (Graham et al. 2016), systemic neonicotinoid biocides and acquired resistance inducers (Graham and Myers 2016), biological control with endophytic bacteria producing quorum sensing inhibitors or toxic secondary metabolites (Daungfu et al. 2019; Villamizar and Caicedo 2019) and bacteriophages (Ibrahim et al. 2017) have been tested. However, a treatment that is operationally viable while ensuring high efficiency, low environmental toxicity and good economic sustainability has not yet been achieved. 
Photodynamic inactivation (PDI) of microorganisms relies on the interaction of a non-toxic photosensitive molecule (photosensitizer, PS), light and molecular oxygen. Once activated by light, the PS catalyzes the formation of reactive oxygen species (ROS) that will induce oxidative damage to lipids, proteins, including enzymes, and nucleic acids, leading to cell death (Wainwright et al. 2017). PDI has several advantages when compared to traditional antimicrobial approaches: it is effective against different types of microorganisms regardless of their antibiotic or antifungal resistance profile; it addresses different molecular targets mainly in external structures and does not depend on the accumulation of PS in the intracellular compartment; it involves cytotoxic agents, particularly singlet oxygen, for which cells lack effective defense or detoxification mechanisms. The development of specific resistance to oxidative stress is not yet demonstrated and only a few dyes are considered as potential substrates of efflux pumps (Cieplik et al. 2018).

Although antitumoral and antimicrobial therapies are historically the most prominent biological applications, PDI has been progressively expanding to fields not directly related to human health (Alves et al. 2015; Jesus et al. 2018; Glueck et al. 2019). PDI targets all groups microorganisms, but they are not evenly susceptible. Gram-positive bacteria are more susceptible to PDI than gram-negative bacteria due to differences in cell wall structure and composition (Almeida et al. 2015) and microbial biofilms are less susceptible than planktonic cells because the extracellular polymeric substances behave as diffusion barriers and ROS quenchers (Beirão et al. 2014; Gambino and Cappitelli 2016). Nevertheless, PDI with synthetic (porphyrins, chlorins, phtalocyanines, among others) and natural (curcumin, riboflavin, etc) PSs has been successfully applied against bacterial, fungal or mixed biofilms (Vilela et al. 2012; Beirão et al. 2014; Bonifácio et al. 2018). Recently, it has been discovered that the 
addition of non-toxic concentrations of inorganic salts like $\mathrm{KI}, \mathrm{KBr}, \mathrm{KSCN}$ or $\mathrm{NaNO}_{2}$ significantly potentiates the photosensitization process to the level of the complete eradication of the otherwise less susceptible microbial targets (Hamblin and Abrahamse 2018; Santos et al. 2019).

Despite the recognized advantages of PDI as an antimicrobial approach, the transposition into phytosanitary applications is still poorly explored. There are, however, promising reports of PDI of the fungi Colletotricum abscissum in citrus (Gonzalez et al., 2017) and Fusarium oxysporum in sprouted wheat seeds (Žudytė and Lukšienè 2019) and the Gram negative bacterium Pseudomonas syringae pv. actinidiae in kiwi plants (Jesus et al. 2018; Martins et al. 2018).

This work aimed at contributing to the development of a photodynamic control protocol for citrus canker. For this purpose, the efficiency of photosensitization of $X$. citri subsp. citri with toluidine blue O (TBO), in presence of KI, was assessed in cell suspensions and biofilms upon irradiation with artificial or natural sunlight.

\section{Results and discussion}

As a first approach, the efficiency of photodynamic inactivation (PDI) was accessed in cell suspensions, by calculating the logarithmic reduction factor of the concentration viable cells determined before and after irradiation. Exposure to white artificial light $\left.(400-700 \mathrm{~nm}, 150 \mathrm{~mW} \mathrm{~cm})^{-2}\right)$ for $60 \min \left(0.540 \mathrm{~kJ} \mathrm{~cm}^{-2}\right)$ in the presence of $80 \mu \mathrm{M}$ TBO caused a $5.8 \log$ inactivation (Fig. 1). The PS concentration increase failed to improve the photodynamic inactivation efficiency. X. citri subsp. citri revealed lower susceptibility to PDI than other Gram negative bacteria. For instance, a lower concentration of TBO $(44 \mu \mathrm{M})$ and smaller light dose $\left(40 \mathrm{~J} \mathrm{~cm}^{-2}\right)$ caused $>8 \log$ inactivation in cell suspensions of Escherichia coli (Usacheva et al. 2001). The lower 
susceptibility of $X$. citri subsp. citri to PDI may be related to genetically encoded mechanisms of protection against oxidative stress, important in the infection process (Loprasert et al. 1996; Fuangthong et al. 2015).

[Fig 1]

The type of PSs determines affinity to target cells, prevailing photosensitization mechanism and ultimately, inactivation efficiency (Alves et al. 2015). When comparing results obtained with cells suspensions using the same platting method (pour platting), porphyrins and chlorins have been reported as attaining higher inactivation factors against some Gram negative phytopathogenic bacteria. X. anoxopodis suffered a $7 \log$ reduction with $10 \mu \mathrm{M}$ of a mixture of cationic derivatives of chlorin $e_{6}$ and an energy dose of $27 \mathrm{~J} \mathrm{~cm}^{-2}$ (Glueck et al. 2019). PDI of Pseudomonas syringae pv. actinidiae (Psa) with a cationic porphyrin produced an inactivation factor equivalent to that obtained in this work $(6 \log )$ with half the concentration of porphyrinic PS $(50 \mu \mathrm{M})$ and a slightly higher light dose (Jesus et al. 2018) and when a mixture of several porphyrin derivatives was used, the factor raised to $7.4 \log$ with only $5.0 \mu \mathrm{M}$ of PS mixture after a total light dose of $14 \mathrm{~J} \mathrm{~cm}^{-2}$ (Martins et al. 2018). However, for the moment, these synthetic PSs are neither affordable nor commercially available for large-scale use.

There was no significant variation in light (LC) and dark (DC) controls (ANOVA, $\mathrm{p}>0.05$ ), indicating that neither the TBO nor KI exhibited cytotoxic effect in the absence of light.

The PDI $X$. citri subsp. citri biofilms attached to polypropylene microtubes (Fig. 2) with $100 \mu \mathrm{M}$ of TBO caused a much smaller reduction $(1.5 \log )$ than observed in cells suspensions, in similar irradiation conditions. The decreased susceptibility of biofilms to PDI, in relation to the planktonic form, has been recurrently reported and leads to the need for higher light doses and PS concentrations (Beirão et al. 2014; 
Bonifácio et al. 2018). The effect is usually attributed to barrier imposed by the extracellular matrix, which limits PS and $\mathrm{O}_{2}$ access to target cell structures, and the ROS-scavenging effect of extracellular polymeric substances (Kishen 2017). However, in presence of $10 \mathrm{mM}$ of KI there was inactivation of the biofilm cells to the limit of detection of the method (6.3-6.6 log), with TBO concentrations as low as $5.0 \mu \mathrm{M}$.

[Fig. 2]

The potentiating effect of non-toxic concentration of KI on the photosensitization of biofilms has been demonstrated for several PSs in various target microorganisms, although in general, with higher KI concentrations. Effective PDI of Candida albicans biofilms required $100 \mu \mathrm{M}$ of methylene blue (MB) and $100 \mathrm{mM} \mathrm{KI}$ (Freire et al. 2016). The addition of $100 \mathrm{mM} \mathrm{KI}$ increased by about $2 \log$ the inactivation factor of biofilms of Enterococcus faecalis with $100 \mu \mathrm{M}$ TBO (Ghaffari et al. 2018) and complete eradication of biofilms of Escherichia coli was attained by combining $1.0 \mu \mathrm{M}$ of a mixture of porphyrinic PS with $100 \mathrm{mM} \mathrm{KI}$ (Vieira et al. 2019). In this study, the combination of $5.0 \mu \mathrm{M}$ TBO and $10 \mathrm{mM} \mathrm{KI}$ was sufficient to reduce the concentration of viable cells in biofilms of $X$. citri subsp. citri to the detection limit, which corresponds to a lower KI concentration than usually used for the PDI of biofilms of other Gram negative bacteria. However, the Miles-Misra method used in the assays with biofilms has a much higher limit of detection than the pour-platting technique.

Complete inactivation would correspond to a $>8$ log reduction that cannot be demonstrated with the former method. With $1.0 \mu \mathrm{M} \mathrm{TBO}+1.0 \mathrm{mM} \mathrm{KI}$, there was a small (1.3 log), albeit significant (ANOVA, $\mathrm{p}<0.05$ ) photodynamic inactivation of biofilm cells. Light (LC) and dark (DC) controls confirm that like planktonic cells, 
biofilms are not susceptible to light and that neither TBO nor KI have inhibitory effect in the dark.

[Fig. 3]

The ex vivo assays of PDI of biofilms of $X$. citri subsp. citri on the surface of orange tree leaves had the dual purpose of evaluating if under these conditions the same inactivation efficiency as in the in vitro assays could be achieved and also detecting eventual damages in the integrity of the leaves. Under artificial light, complete eradication of biofilms (log reduction $\sim 6 \log$ ) occurred in presence of $100 \mathrm{mM} \mathrm{KI}$, with TBO concentrations ranging 5-100 $\mu \mathrm{M}$ (Fig. 3) despite the fact that the photodynamic inactivation efficiency was lower than in vitro. Although the combination of $5.0 \mu \mathrm{M}$ $\mathrm{TBO}+10 \mathrm{~mm} \mathrm{KI}$ that produced complete inactivation of biofilms in vitro was not tested, the combination corresponding to a higher PS concentration $(10 \mu \mathrm{M}$ TBO +10 mM KI) caused a reduction of only $6.3 \log (>99.9999 \%)$. Nevertheless, complete eradication of the biofilms was achieved in presence of $100 \mathrm{mM} \mathrm{KI}$. The reduction in PDI efficiency in ex vivo conditions, compared to in vitro assays, was also observed in PDI of Psa on kiwi leaves (Jesus et al. 2018) and may be related to protection and shading caused by leaf micro-texture and sheltering provided by the stomata. Another effect may be associated with the experimental design. In the in vitro assays, the biofilms were immersed in the PS-containing solution during irradiation PS whereas in the ex vivo assays, the biofilms were pre-exposed to the PS during the dark incubation period but later removed from the PS-containing solution. Therefore, in the ex vivo assays, the PS availability is restricted to the molecules that actually bound the biofilms during the dark exposure period. Nevertheless, complete eradication of the biofilms with cationic porphyrins was achieved without visible leaf damage (Jesus et al. 2018) as 
opposed to what is observed with anionic porphyrins that can cause plant cell death (Leroy-Lhez et al. 2019).

Envisaging the transposition of PDI protocol to field conditions, the biofilm PDI on orange leaves was tested under natural sunlight irradiation (Fig. 4). Since sunlight irradiance was lower (23-60 $\left.\mathrm{mW} \mathrm{cm}^{-2}\right)$, irradiation time was extended up to $4 \mathrm{~h}$ to reach a similar total energy dose $\left(\sim 0.6 \mathrm{~kJ} \mathrm{~cm}^{-2}\right)$ to that used in the experiments under artificial white light. Under these experimental conditions with $100 \mathrm{mM} \mathrm{KI}$, there was complete inactivation of the biofilms with TBO concentrations higher than $50 \mu \mathrm{M}$ and a $3.6 \log$ reduction with concentration of $20 \mu \mathrm{M}$ of TBO. The results indicate that under natural sunlight irradiation, the photosensitization process was less efficient than under artificial light conditions. Whereas with artificial light complete eradication ( $6 \log$ reduction) of the biofilms was achieved with $5.0 \mu \mathrm{M}$ TBO $+100 \mathrm{mM} \mathrm{KI}$, with natural sunlight a 10 fold higher of PS concentration was required. This may be a consequence of the different spectra of the artificial light source and natural sunlight (Supporting Information). TBO has a peak of absorbance at 630 and the peak of energy of artificial light is centered around $580 \mathrm{~nm}$, whereas in natural sunlight the peak occurs closer to $500 \mathrm{~nm}$. Therefore, artificial light is likely to deliver more energy to the PS than natural sunlight. Also, natural sunlight contains UV, which is absent from the emission spectrum of artificial light, and may induce the photodegradation of the PS.

Phenothiazine dyes are susceptible to photo-reduction (Koizumi et al., 1964) that in the case of prolonged exposure to solar irradiation, could cause an effective loss of PS.

However, complete eradication of the biofilm was still attained within $4 \mathrm{~h}$, without visible damage to the leaves and, in this case, better preserving the freshness and turgidity of the leaves. 
So far, no leaf damage caused by the direct contact with the PS was detected in

221

222

223

224

225

226

227

\section{Materials and methods}

[Fig. 4]

long experiments (2 week-trials without PS re-application) of PDI of Colletotrichum on young orange trees exposed to sunlight (de Menezes et al. 2014). Also, leaf damage caused by KI has not been reported, for concentrations up to $100 \mathrm{mM}$. However, the effect of long term exposure to TBO and KI has not yet been tested.

As conclusion, the phytopathogenic $X$. citri subsp. citri is less susceptible to PDI than other Gram negative bacteria, particularly in the biofilm forms. However, photosensitization with TBO in presence of KI produces a significant reduction in viable cell concentration. It was possible to completely eradicate leaf biofilms with 50 $\mu \mathrm{M}$ TBO and $100 \mathrm{mM} \mathrm{KI}$ after $4 \mathrm{~h}$ of exposure to indirectly applied natural sunlight. These results allow us to expect that complete photodynamic inactivation may be reached with even lower PS concentrations in a full day light exposure $(\sim 12 \mathrm{~h})$. Visual inspection of leaves revealed no damage, which indicates good TBO compatibility with plant tissue. However, it will also be important to evaluate other physiologic parameters, namely chlorophyll content, that may provide information on potential negative effects of TBO on photosynthetic performance. The fact that TBO is susceptible to photo-reduction upon prolonged irradiation can represent an advantage considering the use for phyto-sanitary applications as it reduces the risks of accumulation in the environment. Therefore, PDI with TBO represents a promising perspective for a cost-effective and environmentally sustainable alternative to chemical biocides for control of citrus cancer.

\section{Photosensitizer and coadjutant solutions}


Scientific, Cheshire, UK) was prepared in distilled water and stored at room

temperature. Prior to each assay, TBO and KI stock solutions were sonicated for $30 \mathrm{~min}$ to ensure complete homogeneity of the solution.

\section{Preparation of bacterial cultures, cells suspensions and biofilms} provided by Prof. William Nunes (State University Maringá, Brazil). Prior to each assay, a fresh stationary-phase culture $\left(\mathrm{OD}_{600} \sim 0.8\right)$ in Tryptic Soy Broth (TSB, Liofilchem, Roseto degli Abruzzi, Italy) was prepared (18 h at $37^{\circ} \mathrm{C}$ under $\left.180 \mathrm{rpm}\right)$. Cell suspensions were obtained by diluting $(1: 10)$ the fresh culture in phosphate saline buffer (PBS, pH 7.2). For the preparation of biofilms on the internal surface of microtubes (in vitro assays), $1 \mathrm{~mL}$-aliquots of fresh culture were transferred to sterile $1.5 \mathrm{~mL}$ polypropylene microtubes. After $24 \mathrm{~h}$ incubation at $37^{\circ} \mathrm{C}$ (without agitation) the medium was discarded, the microtube walls were gently rinsed with $1.0 \mathrm{~mL}$ PBS for removal of loosely attached cells and $1.0 \mathrm{~mL}$ of fresh TSB was added to each tube.

Biofilms were allowed to mature for $48 \mathrm{~h}$ at $37^{\circ} \mathrm{C}$, without agitation, and before the PDI assays, the medium was discarded and the biofilm was gently rinsed with sterile PBS. For the ex vivo assays, freshly harvested orange tree leaves were washed with distilled water and dried with filter. On the upper page of each leaf, three squares $(2 \times 2 \mathrm{~cm})$ were drawn with permanent marker. The leaves were sterilized by60 min of immersion in $1 \%$ hydrogen peroxide and 15 min UV irradiation on each page. Sterilized leaves were immersed $\left(30 \mathrm{~min}\right.$ at $\left.37^{\circ} \mathrm{C}\right)$ on a 1:10 dilution in PBS of a fresh TSB culture of 
the bacterium. Inoculated leaves were individually transferred to petri dishes containing $15 \mathrm{~mL}$ PBS and incubated for $48 \mathrm{~h}$ at $37^{\circ} \mathrm{C}$ for biofilm maturation. Whenever necessary, sterile PBS was added to the bottom of the plate to prevent leaf dehydration.

\section{Photodynamic inactivation experiments}

For the PDI of cell suspensions, the solution of TBO was added directly to the suspension to achieve the work concentration of $80 \mu \mathrm{M}$. For the in vitro assays of biofilm PDI, $1.0 \mathrm{~mL}$ of PBS was added to each microtube and the solutions of TBO and KI were added to achieve the work concentrations (1-100 $\mu \mathrm{M}$ TBO and 1-100 mM KI). For the ex vivo assays of biofilm PDI, the leaves on which biofilms developed were immersed in PBS containing the work concentrations of TBO and KI (5-100 $\mu \mathrm{M}$ TBO and 10 or $100 \mu \mathrm{M} \mathrm{KI}$ ). Once in contact with the PS, cell suspensions and biofilms were incubated in the dark, at $37{ }^{\circ} \mathrm{C}$, during $30 \mathrm{~min}$. After dark incubation, leaves used in the ex vivo assays were removed from the solutions and placed on petri plates containing 15 $\mathrm{mL}$ of PBS (underneath the leaf) to avoid excessive desiccation during irradiation.

For PDI assays with artificial light, cell suspensions and biofilms, either in microtubes or on the surface of orange tree leaves, were irradiated during 60 min with artificial white light (400-800 $\mathrm{nm} ; 150 \mathrm{~mW} \mathrm{~cm}^{-2}$ ) delivered by a $250 \mathrm{~W}$ quartz/halogen lamp system equipped with a fiber optic probe (LumaCare s Model 122, Newport Beach, USA). In PDI assays with natural sunlight (350-850 nm; 23-60 mW cm-2, according to CliM@UA; http://climetua.fis.ua.pt/weather/solar_radiation/aveiro), irradiation was conducted for $4 \mathrm{~h}$.

\section{Calculation of the logarithmic reduction factor}



cell suspensions and biofilms. For the quantification of viable cells in suspensions, aliquots were serially diluted in PBS and pour-plated in triplicate in Tryptic Soy Agar

297 (TSA, Liofilchem, TSB, Liofilchem, Roseto degli Abruzzi, Italy). For the analysis of biofilms in microtubes, each microtube was sonicated for $90 \mathrm{~s}\left(\right.$ Silvercrest $^{\circledR}$, Neckarsulm, Germany) and homogenized in the vortex for $60 \mathrm{~s}$. The homogenized suspensions were serially diluted in PBS and platted in triplicate in TSA by the MilesMisra method. Biofilms on leaves were scrapped from the 2 x $2 \mathrm{~cm}$ squares with a swab, resuspended in $1.0 \mathrm{~mL}$ PBS, and thereafter treated as biofilms in microtubes. Cultures were incubated for $24 \mathrm{~h}$ at $37^{\circ} \mathrm{C}$ and colony forming units (CFU) were counted in the replicates of the most suitable dilution. The inactivation efficiency was calculated as the logarithmic reduction in the concentration of viable cells during the period corresponding to irradiation of the tests.

Controls were included in all assays. Light controls (LC) were exposed to the same irradiation conditions as the tests, without addition of the TBO and KI. Dark controls received the highest tested concentrations of $\mathrm{TBO}, \mathrm{KI}$ or $\mathrm{TBO}+\mathrm{KI}$ and were incubated in the dark during a period equivalent to the irradiation of the tests. Each experimental condition was tested in 3 independent assays.

Significance of the differences between treatments was assessed by one-way ANOVA, performed with the GraphPad Prism 6 package, considering $\mathrm{p}<0.05$ as significant.

\section{Acknowledgements}

Thanks are due to the University of Aveiro and FCT/MEC for the financial support to CESAM (UIDB/50017/2020+UIDP/50017/2020), QOPNA (FCT 
UID/QUI/00062/2019) and LAQV-REQUIMTE (UIDB/50006/2020) research units, and to projects PREVINE (PTDC/ASP-PES/29576/2017) and RhiZoMis (PTDC/BIAMIC/2973672017) through national founds and, where applicable, co-financed by the FEDER, within the PT2020 Partnership Agreement.

\section{Conflict of interest}

No conflict of interest declared.

\section{References}

Almeida, A., Faustino, M.A. and Tomé, J.P. (2015) Photodynamic inactivation of bacteria: finding the effective targets. Future Medicinal Chemistry 7, 1221-1224.

Alves, E., Faustino, M.A., Neves, M.G., Cunha, Â., Nadais, H. and Almeida, A. (2015) Potential applications of porphyrins in photodynamic inactivation beyond the medical scope. Journal of Photochemistry and Photobiology C: Photochemistry Reviews 22, 34-57.

Behlau, F., Scandelai, L.H.M., da Silva Junior, G.J. and Lanza, F.E. (2017) Soluble and insoluble copper formulations and metallic copper rate for control of citrus canker on sweet orange trees. Crop Protect 94, 185-191.

Beirão, S., Fernandes, S., Coelho, J., Faustino, M.A., Tomé, J.P., Neves, M.G., Tomé, A.C., Almeida, A. and Cunha, A. (2014) Photodynamic inactivation of bacterial and yeast biofilms with a cationic porphyrin. Photochemistry and Photobiology 90, 1387-1396.

Bonifácio, D., Martins, C., David, B., Lemos, C., Neves, M., Almeida, A., Pinto, D., Faustino, M. and Cunha, Â. (2018) Photodynamic inactivation of Listeria innocua biofilms with food-grade photosensitizers: a curcumin-rich extract of Curcuma longa vs commercial curcumin. J Appl Microbiol 125, 282-294. 
Canteros, B.I., Rybak, M., Gochez, A., Velazquez, P., Rivadeneira, M., Mitidieri, M., Garran, S. and Zequeira, L. (2008) Occurrence of copper resistance in Xanthomonas axonopodis pv. citri in Argentina. Phytopathology 98, S30.

Cieplik, F., Deng, D., Crielaard, W., Buchalla, W., Hellwig, E., Al-Ahmad, A. and Maisch, T. (2018) Antimicrobial photodynamic therapy-what we know and what we don't. Crit Rev Microbiol 44, 571-589.

Daungfu, O., Youpensuk, S. and Lumyong, S. (2019) Endophytic bacteria isolated from citrus plants for biological control of citrus canker in lime plants. Tropical Life Sciences Research 30, 73.

de Menezes, H.D., Rodrigues, G.B., de Pádua Teixeira, S., Massola, N.S., Bachmann, L., Wainwright, M. and Braga, G.U. (2014) In vitro photodynamic inactivation of plantpathogenic fungi Colletotrichum acutatum and Colletotrichum gloeosporioides with novel phenothiazinium photosensitizers. Appl Environ Microb 80, 1623-1632.

Favaro, M.A., Roeschlin, R.A., Ribero, G.G., Maumary, R.L., Fernandez, L.N., Lutz, A., Sillon, M., Rista, L.M., Marano, M.R. and Gariglio, N.F. (2017) Relationships between copper content in orange leaves, bacterial biofilm formation and citrus canker disease control after different copper treatments. Crop Protect 92, 182-189.

Freire, F., Ferraresi, C., Jorge, A.O.C. and Hamblin, M.R. (2016) Photodynamic therapy of oral Candida infection in a mouse model. J Photochem Photobiol B: Biol 159, 161-168.

Fuangthong, M., Jittawuttipoka, T., Wisitkamol, R., Romsang, A., Duang-nkern, J., Vattanaviboon, P. and Mongkolsuk, S. (2015) IscR plays a role in oxidative stress resistance and pathogenicity of a plant pathogen, Xanthomonas campestris. Microbiol Res 170, 139-146.

Gambino, M. and Cappitelli, F. (2016) Mini-review: biofilm responses to oxidative stress. Biofouling 32, 167-178. 
Ghaffari, S., Sarp, A.S.K., Lange, D. and Gülsoy, M. (2018) Potassium iodide potentiated photodynamic inactivation of Enterococcus faecalis using toluidine blue: comparative analysis and post-treatment biofilm formation study. Photodiagnosis and Photodynamic Therapy 24, 245-249.

Glibota, N., Grande Burgos, M.J., Gálvez, A. and Ortega, E. (2019) Copper tolerance and antibiotic resistance in soil bacteria from olive tree agricultural fields routinely treated with copper compounds. J Sci Food Agric 99, 4677-4685.

Glueck, M., Hamminger, C., Fefer, M., Liu, J. and Plaetzer, K. (2019) Save the crop: Photodynamic Inactivation of plant pathogens I: bacteria. Photoch Photobio Sci.

Gonçalves-Zuliani, A.M., Nunes, W., Zanutto, C.A., Filho, J.C. and Nocchi, P.T. (2015) Evaluation of susceptibility of 'Pêra' sweet orange genotypes to ctrus canker under field and greenhouse conditions. Acta Horticulturae 62.

Graham, J., Johnson, E., Myers, M., Young, M., Rajasekaran, P., Das, S. and Santra, S. (2016) Potential of nano-formulated zinc oxide for control of citrus canker on grapefruit trees. Plant Dis 100, 2442-2447.

Graham, J.H. and Myers, M.E. (2016) Evaluation of soil applied systemic acquired resistance inducers integrated with copper bactericide sprays for control of citrus canker on bearing grapefruit trees. Crop Protect 90, 157-162.

Hamblin, M.R. and Abrahamse, H. (2018) Inorganic salts and antimicrobial photodynamic therapy: mechanistic conundrums? Molecules 23, 3190.

Ibrahim, Y.E., Saleh, A.A. and AI-Saleh, M.A. (2017) Management of asiatic citrus canker under field conditions in Saudi Arabia using bacteriophages and acibenzolar-S-methyl. Plant Dis 101, 761-765.

Jesus, V., Martins, D., Branco, T., Valério, N., Neves, M.G., Faustino, M.A., Reis, L., Barreal, E., Gallego, P.P. and Almeida, A. (2018) An insight into the photodynamic approach versus 
copper formulations in the control of Pseudomonas syringae pv. actinidiae in kiwi plants. Photoch Photobio Sci 17, 180-191.

Kishen, A. (2017) Microbial biofilms and antimicrobial photodynamic therapy. In Imaging in Photodynamic Therapy. pp.111-124: CRC Press.

Lamichhane, J.R., Osdaghi, E., Behlau, F., Köhl, J., Jones, J.B. and Aubertot, J.-N. (2018) Thirteen decades of antimicrobial copper compounds applied in agriculture. A review. Agronomy

Lanza, F.E., Marti, W., Silva Jr, G.J. and Behlau, F. (2018) Characteristics of citrus canker lesions 401 associated with premature drop of sweet orange fruit. Phytopathology 109, 44-51.

Leroy-Lhez, S., Rezazgui, O., Issawi, M., Elhabiri, M., Calliste, C.A. and Riou, C. (2019) Why are the anionic porphyrins so efficient to induce plant cell death? A structure-activity relationship study to solve the puzzle. J Photochem Photobiol A: Chem 368, 276-289.

Loprasert, S., Vattanaviboon, P., Praituan, W., Chamnongpol, S. and Mongkolsuk, S. (1996) Regulation of the oxidative stress protective enzymes, catalase and superoxide dismutase in Xanthomonas - a review. Gene 179, 33-37.

Martins, D., Mesquita, M.Q., Neves, M.G., Faustino, M.A., Reis, L., Figueira, E. and Almeida, A. (2018) Photoinactivation of Pseudomonas syringae pv. actinidiae in kiwifruit plants by cationic porphyrins. Planta 248, 409-421.

Roach, R., Mann, R., Gambley, C., Shivas, R., Chapman, T. and Rodoni, B. (2020) Pathogenicity and copper tolerance in Australian Xanthomonas species associated with bacterial leaf spot. Crop Protect 127, 104923.

Santos, A.R., Batista, A.F., Gomes, A.T., Neves, M.d.G.P., Faustino, M.A.F., Almeida, A., Hioka, N. and Mikcha, J.M. (2019) The remarkable effect of potassium iodide in eosin and rose bengal photodynamic action against Salmonella typhimurium and Staphylococcus aureus. Antibiotics 8, 211. 
Savietto, A., Polaquini, C.R., Kopacz, M., Scheffers, D.-J., Marques, B.C., Regasini, L.O. and Ferreira, H. (2018) Antibacterial activity of monoacetylated alkyl gallates against Xanthomonas citri subsp. citri. Arch Microbiol 200, 929-937.

Usacheva, M.N., Teichert, M.C. and Biel, M.A. (2001) Comparison of the methylene blue and toluidine blue photobactericidal efficacy against gram-positive and gram-negative microorganisms. Lasers in Surgery and Medicine 29, 165-173.

Vieira, C., Santos, A., Mesquita, M.Q., Gomes, A.T., Neves, M.G.P., Faustino, M.A.F. and Almeida, A. (2019) Advances in aPDT based on the combination of a porphyrinic formulation with potassium iodide: Effectiveness on bacteria and fungi planktonic/biofilm forms and viruses. J Porphyr Phthalocya 23, 534-545.

Vilela, S.F.G., Junqueira, J.C., Barbosa, J.O., Majewski, M., Munin, E. and Jorge, A.O.C. (2012) Photodynamic inactivation of Staphylococcus aureus and Escherichia coli biofilms by malachite green and phenothiazine dyes: An in vitro study. Arch Oral Biol 57, 704-710.

Villamizar, S. and Caicedo, J.C. (2019) Biological Control of Citrus Canker: New Approach for Disease Control. In Plant Pathology and Management of Plant Diseases: IntechOpen.

Wainwright, M., Maisch, T., Nonell, S., Plaetzer, K., Almeida, A., Tegos, G.P. and Hamblin, M.R. (2017) Photoantimicrobials - are we afraid of the light? The Lancet Infectious Diseases 17, e49-e55.

Žudytè, B. and Lukšienè, ž. (2019) Toward better microbial safety of wheat sprouts: chlorophyllin-based photosensitization of seeds. Photoch Photobio Sci 18, 2521-2530. 


\section{$440 \quad$ Figure Legends}

441 Figure 1. Logarithmic reduction of the concentration of viable cells in suspensions of

442 Xanthomonas citri subsp. citri irradiated with artificial white light $\left(150 \mathrm{~mW} \mathrm{~cm} \mathrm{~cm}^{-2}\right)$ for

$44360 \mathrm{~min}\left(0.540 \mathrm{~kJ} \mathrm{~cm}^{-2}\right)$, in presence of TBO. Error bars represent the standard deviation

444 of 3 independent assays with replicates.

446 Figure 2. Logarithmic reduction of the concentration of viable cells in biofilms of

447 Xanthomonas citri subsp. citri adherent to polypropylene microtubes, irradiated with artificial white light $\left(150 \mathrm{~mW} \mathrm{~cm} \mathrm{~cm}^{-2}\right)$ for $60 \min \left(0.540 \mathrm{~kJ} \mathrm{~cm}^{-2}\right)$, in presence of TBO and

KI. Error bars represent the standard deviation of 3 independent assays. * indicates absence in the $10 \mu \mathrm{L}$ aliquots (complete eradication).

Figure 3. Logarithmic reduction of the concentration of viable cells in biofilms of

Xanthomonas citri subsp. citri on the surface of orange tree leaves, irradiated with artificial white light $\left.(150 \mathrm{~mW} \mathrm{~cm})^{-2}\right)$ for $60 \min \left(0.540 \mathrm{~kJ} \mathrm{~cm}^{-2}\right)$, in presence of TBO and KI. Error bars represent the standard deviation of 3 independent assays. * indicates absence in $10 \mu \mathrm{L}$ aliquots (complete eradication).

457

Figure 4. Logarithmic reduction of the concentration of viable cells in biofilms of Xanthomonas citri subsp. citri on the surface of orange tree leaves, irradiated with natural sunlight for $4 \mathrm{~h}\left(\sim 0.6 \mathrm{~kJ} \mathrm{~cm}{ }^{-2}\right)$, in presence of TBO and KI. Error bars represent

461 the standard deviation of 3 independent assays. * indicates absence in $10 \mu \mathrm{L}$ aliquots. 
Cell suspensions

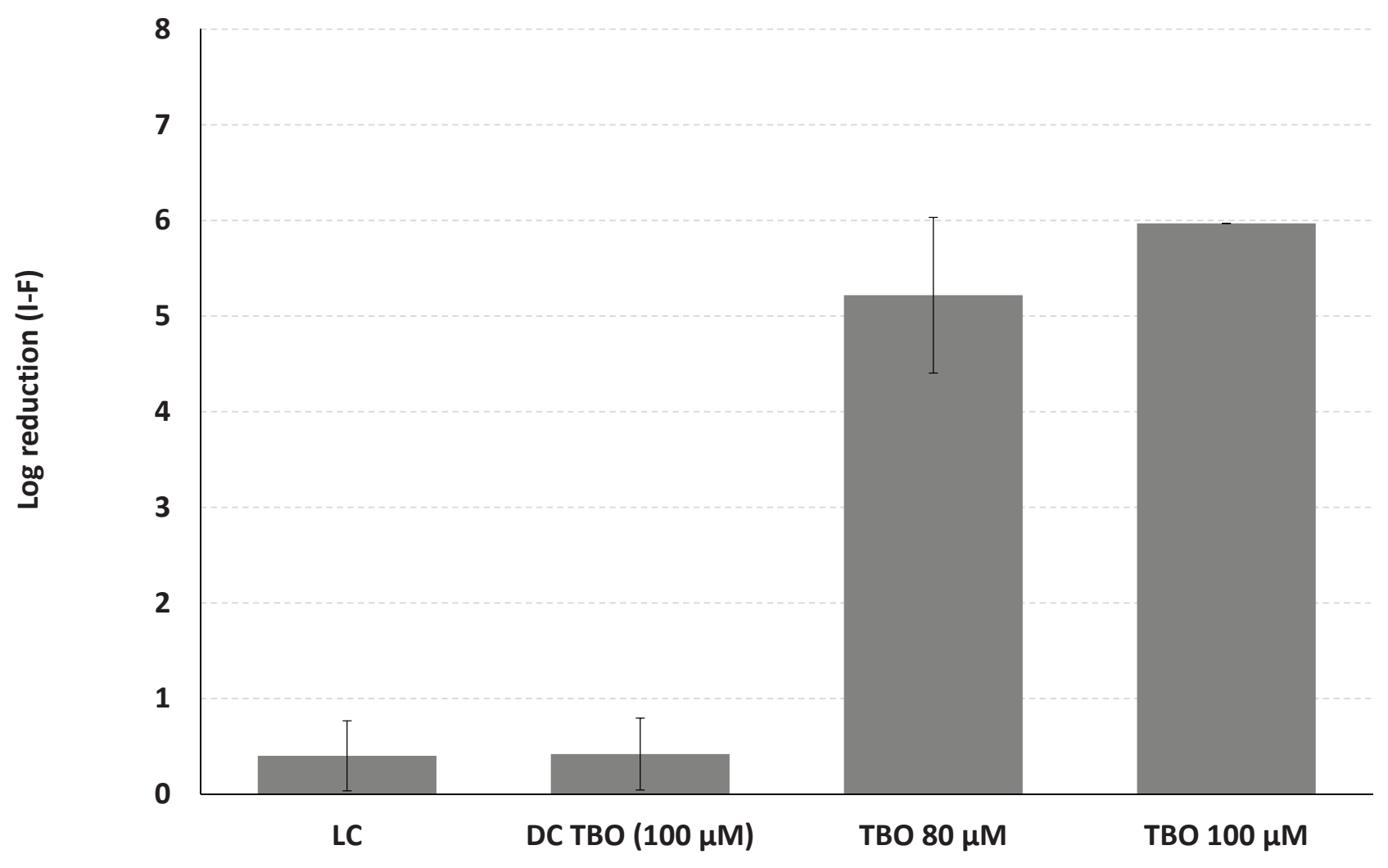


Biofilms

in vitro

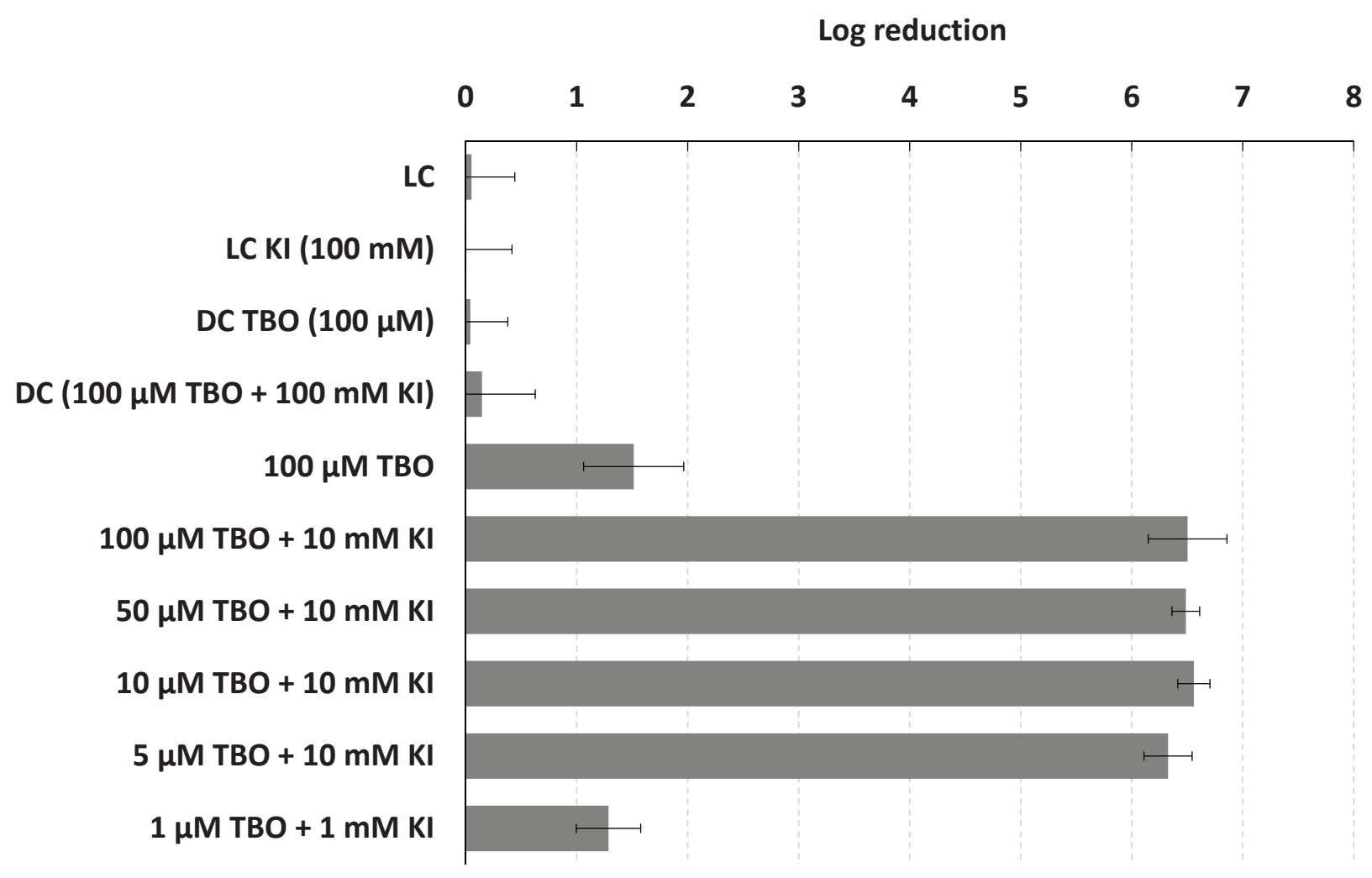




\section{Biofilms \\ ex vivo assays with artificial light}

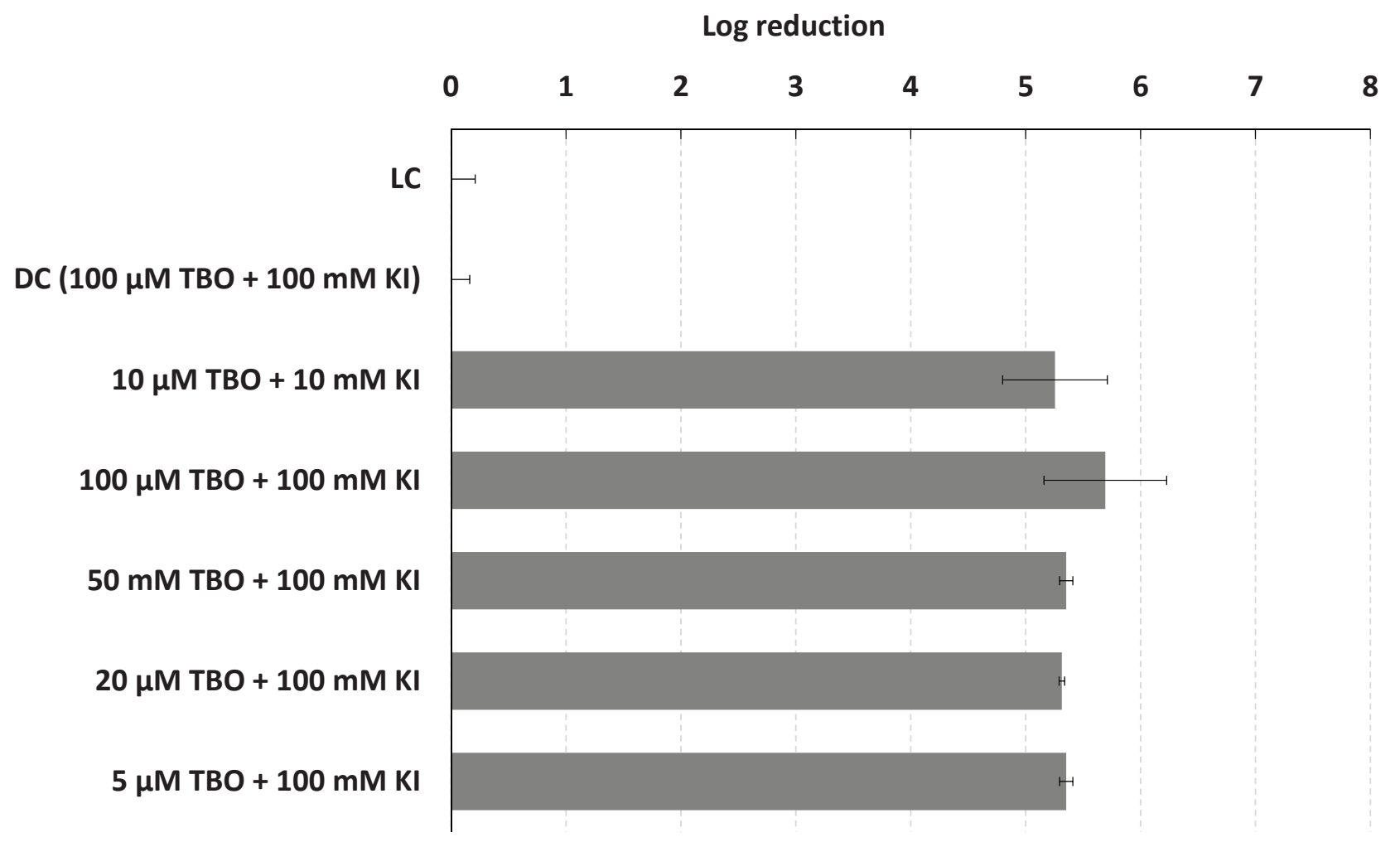




\section{Biofilms}

\section{ex vivo assays with natural sunlight}

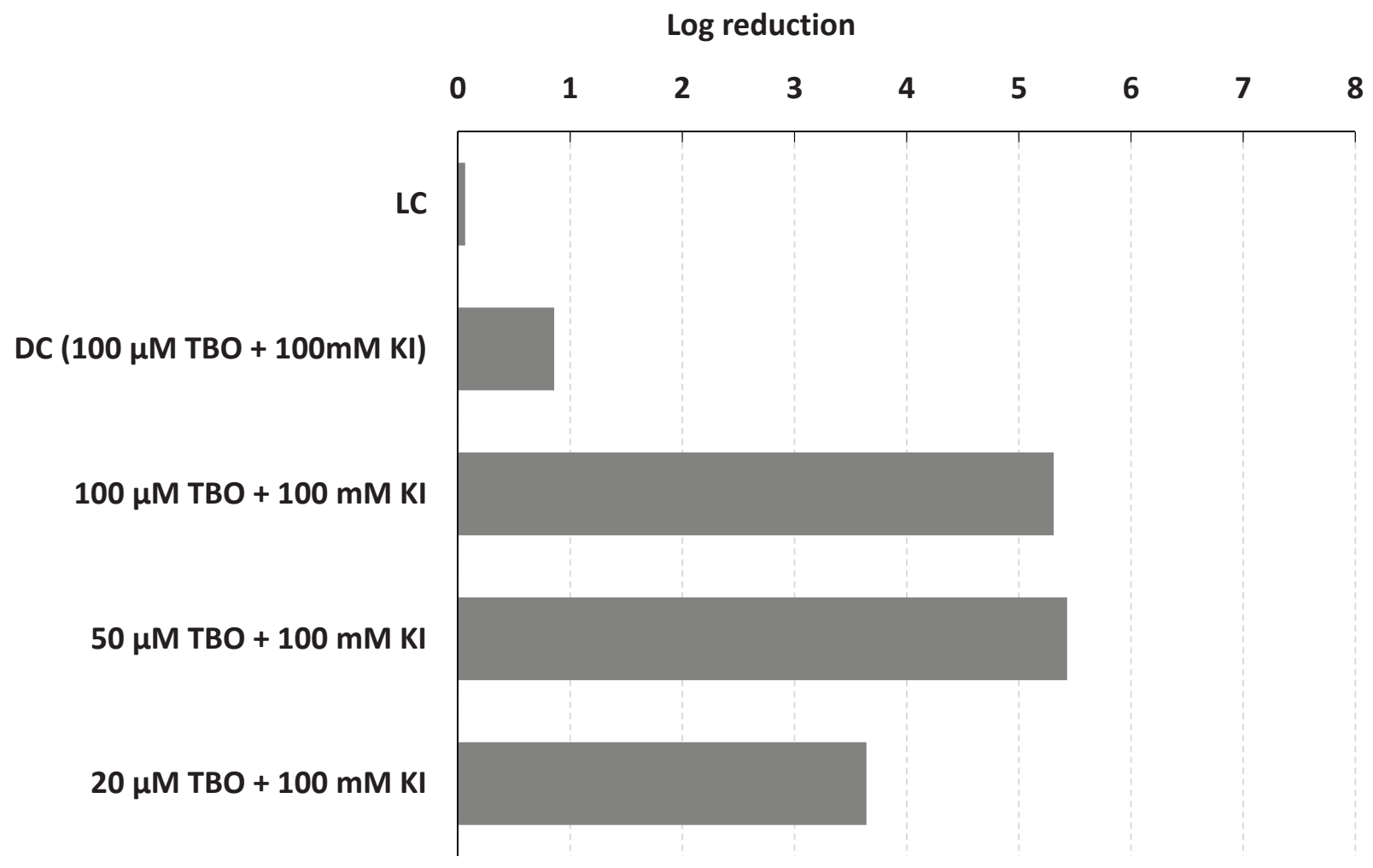




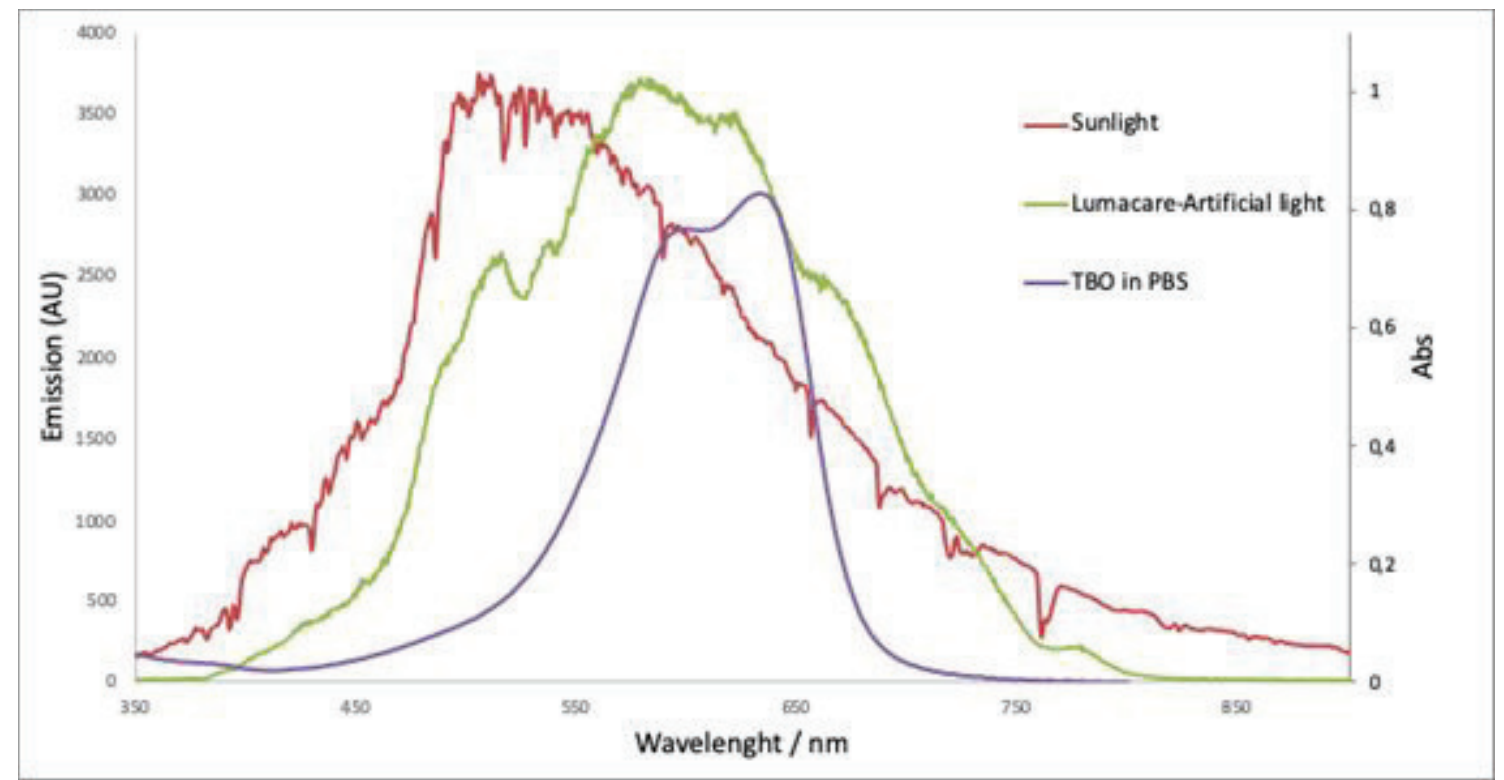

Figure S1 Absorption spectrum of Toluidine Blue O (TBO) dissolved in phosphate saline buffer (PBS) and emission spectra of natural sunlight and artificial white light delivered by the Lumacare 122 system coupled to a light fiber probe (400-800 nm). 


\section{Page 48 of 49}

